\title{
Our Land, Our People: A Reflection of Tibetan Buddhist Space in Contemporary Art
}

\author{
Jay Daugherty
}

This article illustrates how a contemporary

Tibetan artist disrupts expectations in the creation of his political art. Utilizing Robert Smithson's dialogic of site and non-site, Tenzing Rigdol's 2011 site-specific installation Our Land, Our People is interpreted as a reenactment of a culturally specific historical practice of moving space. This approach shares important similarities to historical cases in which physical spaces were relocated to and within Tibet, allowing for the application of $20^{\text {th }}$ century theories arising in the spatial turn to contemporary Tibetan art.
Keywords: contemporary art; Tibet; phenomenology; space; Tenzing Rigdol 


\section{Introduction}

While the perceived link between the purity of the Tibetan landscape and its inhabitants remains a popular topic in discussions surrounding Tibetan culture, contemporary Tibetan artists often disrupt traditional expectations by juxtaposing cultural spaces and modern contexts in the creation of their political art. This article looks beyond ritual landscape to apply theories arising in the spatial turn and Robert Smithson's dialectic of sites and non-sites to Tenzing Rigdol's 2011 site-specific installation Our Land, Our People. Demonstrated to function both as a 'signified object' or real space and simultaneously as a 'signifier' or reference to a location existing elsewhere, this work of art revitalizes a culturally specific, historical practice in which physical spaces were relocated to and within Tibet. When considered alongside the history of the Devikoța pitha described in the Cakrasamvara Tantra, Rigdol's contemporary art installation reveals a continuity in the phenomenology of Tibetan Buddhist space.

\section{Towards a Phenomenology of Tibetan Buddhist Space}

Prior to the first international exhibition of contemporary Tibetan art in 2005 (Harris, 2012: 154), spatial theories rose to prominence in the late 1980s. Authors like Henri Lefebvre, Foucault (1991), Harvey (1993), Soja $(1989,1996)$, and others, generated momentum for such theories to be continually applied across intellectual disciplines (Gilhuly and Worman 2014; Horden and Purcell; Van Dyck and Alcock 2003; Robinson 2011; Osborne 1987; Cole 2004). To the extent the spatial turn appears in Tibet studies, it is recognizable as a sub-genre dedicated to pilgrimage, sacred landscape, religious practices, and related mythologies. While there is growing interest in how political space and symbolic geography are represented in contemporary literature, much of this work is dedicated to pre-modern Tibet and these ideas have yet to be applied to Tibet's contemporary art scene. The present analysis conveys how cultural ideas about Tibetan Buddhist space are vital to understanding the intentions of the artist.

The assertion of phenomenology is that notions construct lived experience through a matrix of assumptions and presuppositions. This confluence ultimately results in the conventional world humanity relies upon, a kind of echo chamber in which society informs conception and vice versa, but which is separate from the natural world. Lefebvre described a "spatial body" from which the basic conception of reality is generated (Lefebvre, 1991:194-196). Life experienced in a human form orients the mind within the environment through physical limitations. A helpful parallel may be drawn with how language structures thoughts. If words are considered the constituent material of thoughts, then a person's thoughts are restricted by vocabulary and syntax. Similarly, a reality which exists beyond the limits of a person's bodily perceptions is unfathomable. By accepting space as a "necessary structural role" within cognition, it is possible to see how a logic of space is predicated on physical movement (Merleau-Ponty, 2002: 313). This framework may then be the recipient of projected cultural notions that have metaphysical, ontological, and soteriological dimensions. However, Gavin Flood offers a meaningful counterpoint in his claim that phenomenology "carries with it Husserlian assumptions about the transcendental ego and an overarching rationality... [and] smuggles into the phenomenology of religion a Husserlian philosophy of consciousness" (Flood 1999: 155). While Lefebvre and Merleau-Ponty state that space structures perception, Flood wisely warns against essentializing this structure as an inherent element of consciousness.

This last point is especially important. While the present discussion concerns historical instances in which the treatment of Buddhist spaces in Tibet parallel Rigdol's installation, it is beyond the scope of the present text to account for all non-Buddhist aspects of Tibet's cultural history, the rich variety of regional differences in conceptualizing space, as well as the lived experiences of Tibetans living in the Tibetan Autonomous Region and the diaspora. However, there are intriguing links in Tibetan language and cultural history that pertain to the ways in which spaces and locations are understood. For example, something as incidental as the Tibetan word sa means both 'place' and 'earth.' From a linguistic standpoint, this demonstrates that to stand on soil is understood to mean being somewhere. This may at first appear to be an obvious point, but there can be complex layers of attributions which characterize the topography of Tibet. A single location may be said to comprise the material form of a deity, contain the residual power of spiritual adepts who practiced there, form a container of sacred energy, and be the residence of celestial beings. Further, these attributes can be combined or changed over time, depending on the religious affiliations of local inhabitants. Additionally, for Buddhist adherents who understand their surroundings according to tantric literature, all topographies are further incorporated into an overarching cosmic world system. Therefore, while standing on Tibetan soil may refer to being somewhere in a casual sense, it can also mean being in a specific location within a larger, complex, multivalent system of ontological stratifications.

In his assessment of Heidegger's essay "Art and Space" (1969), Paul Crowther wrote: "Place comes into being not 
only through the relation between things, but through the event of their coming together to define a certain location, and even more importantly, through their enduring together, and individually, through time" (Crowther, 2013: 70). In this sense, the conceptual framework of Tibetan Buddhist space both influences the behavior of inhabitants who subscribe to this framework and underpins their worldview. Tibetan Buddhist sites can be defined in relation to a specific object or localized essence, and the site can obtain a distinct identity capable of expressing agency. Two examples of this include Tsibri, a mountain in the Tsang region of Tibet believed to have voluntarily relocated from Bodhgaya, India to conceal a poisonous lake, and Potalaka, another Indian mountain said to be the home of the bodhisattva, Avalokiteśvara, which supposedly moved to Lhasa, the capital city of Tibet (Quintman 2008: 367). As locations like these endured through time, they came to characterize aspects of Buddhist culture in Tibet, resulting in the proliferation of movable spaces and single sites that exist in multiple locations simultaneously.

There are many such examples of locations being transported to Tibet, like the two mountains mentioned above or the eight charnel grounds utilized in tantric rites. Buddhist sites in India, including the Mahābodhi temple, the location of the Buddha's enlightenment, have been duplicated abroad in Burma, Nepal, and at Lung Ngön monastery in the Golog area of Tibet (Buffertrille 2015: 135). Additional sites duplicated at Lung Ngön during the 1990s include the ancient stūpa or monument built at Sarnath to mark the place where the Buddha delivered his first sermon, the main temple of Samye, the first Buddhist monastery built in Tibet, and the Bodhnāth Stūpa of Kathmandu, which is associated with the Tibetan emperor Trisong Detsen (755-797). Gathered in one convenient location, these structures provide visitors to the monastery an opportunity to visit duplicated sites from the historical Buddha's life, the Tibetan Empire, and masters of the Kagyu lineage. (Buffertrille, 2015: 138,142).

During her investigation at Lung Ngön monastery, the scholar Katia Buffertrille recounted the motivation for producing these duplications: "When the pilgrim could not go to the pilgrimage, the pilgrimage was brought to the pilgrim" (Buffertrille, 2015: 144). While the reasons for reproducing a holy site are complex, ranging from religious veneration, economic prosperity, and the legitimation of political power, Buffertrille's observation demonstrates the charmingly pragmatic reception these sites receive. The fact of being a replica seems to have no negative impact on their perceived authenticity. In fact, the replicated sites are considered to possess the same degree of power as the original locations. This means thirteen circumambulations around Mount Tarab is considered equal to one circuit around Mount Kailash (Buffetrille, 2015: 145). From this perspective, increasing the number of sacred mountains or Mahābodhi temples means supplying greater access to the karmic benefits of pilgrimage and ensures the promulgation of Buddhism.

Moreover, to reiterate the symbolic importance of mountains, they form distinct cosmological templates outlined in the Abhidharmakośa and Kālacakra Tantras. The macrocosmic world systems described in these texts revolve around a central cosmic mountain. This system is believed to be analogous to a subtle energy network operating inside the body of the practitioner. Spiritual practices incorporating the subtle body effectively unite the three layers of microcosmic, topographical, and macrocosmic space into a single conceptual entity, making it possible to conceptualize processes that hover on the brink of non-conceptual thought. At pilgrimage sites like the twenty-four pithas identified in the Cakrasamvara Tantra, for example, physical spaces or 'sacred seats' located in the landscape act as metaphysical junctions where the practitioner may concurrently operate on all three levels of space.

With Gavin Flood's warning of a Husserlian philosophy of consciousness in mind, and recognizing that there are many nuances influencing conceptions of Tibetan Buddhist space, it is clear that these conceptions are not ahistorical, undialectical, or affiliated with a super-consciousness. Rather, they form a series of thought-structures upon which cultural representations of reality have been projected throughout time, and from which individuals have derived a variety of interpretations that contain similar characteristics. These aspects mirror prevailing notions of space found throughout South and Southeast Asia prior to vernacularization, a time when "Mount Meru and the Ganga were locatable everywhere" and, as Sheldon Pollock explained, this is "nothing in the least mystical" but rather "a function of a different, plural, premodern logic of space" (Pollock, 2006: 16). While contemporary Tibetans living within the Tibet Autonomous Region or the global diaspora may not continue to understand their spatial environment in this way, the legacy of Tibetan Buddhist space has helped shape how cultural spaces are understood.

\section{Tenzing Rigdol \& Our Land, Our People}

The documentary Bringing Tibet Home, directed by Tenzin Tsetan Choklay, details how Tenzing Rigdol orchestrated 


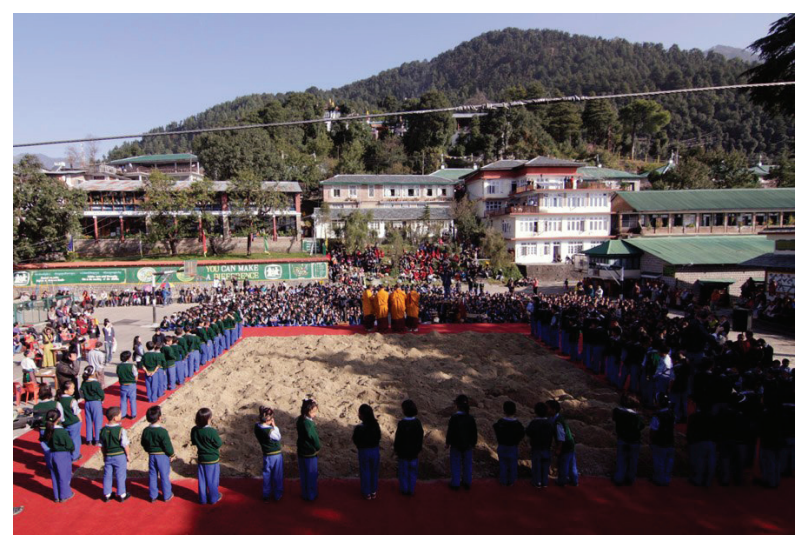

Figure 1: Our Land, Our People, Tenzing Rigdol 2011 Courtesy of the artist and Rossi \& Rossi Gallery

what will likely be one of the most well-known installations of his artistic career. Initially inspired by his father, Norbu Wangdu, who wished to return to Tibet but passed away before it was possible, Rigdol set out to grant unimpeded access to his homeland through art (Rekjong 2013). The Tibetan title of the film is pha sa bu thug, meaning a boy meets his fatherland. Over the course of seventeen months, twenty thousand kilograms of soil were gathered and smuggled over the national borders of China, Nepal, and India (Figure 1). At one point a border shutdown prompted Rigdol to find an alternative route, which involved slinging bags of Tibetan soil on zip-lines over an unnamed river, soaring out of Tibetan territory into the expectant arms of people waiting on the opposite shore in Nepal. One participant described the extreme danger and paranoia he felt as strangers, most likely plain-clothed Chinese police officers, questioned him about the soil. They claimed the police could enter Nepal for several kilometers and still make arrests. Nevertheless, in Dharamsala a thirty square foot stage was constructed in the athletic field of the Tibetan Children's Village for the soil to be displayed.

The film captures the moment when, on 25 October 2011, Rigdol presented a portion of soil to the Dalai Lama (Figure 2), who inscribed the raw earth with the name of Tibet, bod. A crowd of young students sang from the stage before Lobsang Sangay, the Prime Minister of the Tibetan government-in-exile, stepped onto the soil to mark the installation's official opening to the public. Several international news outlets reported from the scene, including CNN, The Wall Street Journal, Radio Free Asia, and The Independent. Their coverage included pictures of monks blessing the soil and images of residents overwhelmed with emotion. At its core, the installation was a political act which temporarily superimposed one space

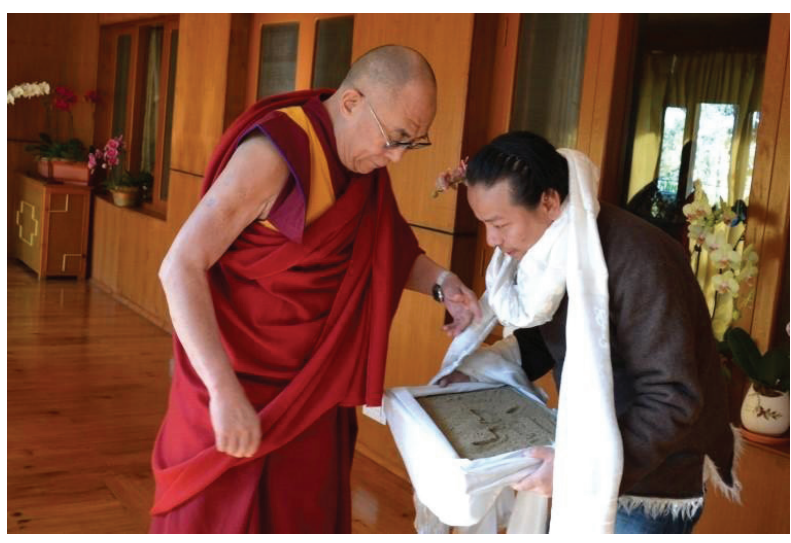

Figure 2: Tenzing Rigdol presents soil to the Dalai Lama Courtesy of the artist and Rossi \& Rossi Gallery

over another. It is this malleability of space which recalls incidents that have reoccurred throughout Tibet's history.

\section{Historical Antecedents: Robert Smithson's Spiral Jetty \& the Devikoța Pițha}

Rigdol's attempt to physically relocate the Tibetan homeland to India is not the first example of contemporary Tibetan installation art. For example, Kesang Lamdark revealed his Pink Himalayan Boulder one week after the 2008 Beijing Olympics, at the Shanghai Contemporary Art Fair (Figure 3). He arranged for a 10,000-kilogram stone to be relocated from Tibet to Shanghai by truck. Despite mostly travelling at night to avoid suspicion, the driver was questioned about an engraving on the boulder, the Tibetan mantra om ma ni pad me hum. When the driver claimed it was a Chinese prayer translated into Tibetan, they were permitted to continue their journey. After arriving in Shanghai, the boulder was placed on a short circular plinth and Lamdark proceeded to carefully wrap the boulder in melted sheets of bubble-gum pink plastic (Masters 2010: 70). When compared with Our Land, Our People, which sought to momentarily rectify the loss of space, Pink Himalayan Boulder presents the materiality of Tibetan space as a souvenir of spiritual materialism, a pre-packaged holy land. Alternatively, Yak Tseten and Tsekal created Arak Stūpa, which is a Buddhist monument made entirely of beer bottles. Exhibited at the highly acclaimed Scorching Sun of Tibet exhibition at Songzhuang Art Center, Beijing (2010), Clare Harris explained Arak Stūpa was an attempt "to acknowledge the post-Maoist and highly consumerist environment that they [the artists] occupy in 'China's Tibet"' (Harris 2012: 160). Considering these examples, contemporary Tibetan installation art appears to rely upon the relationship between a work of art and the context in 


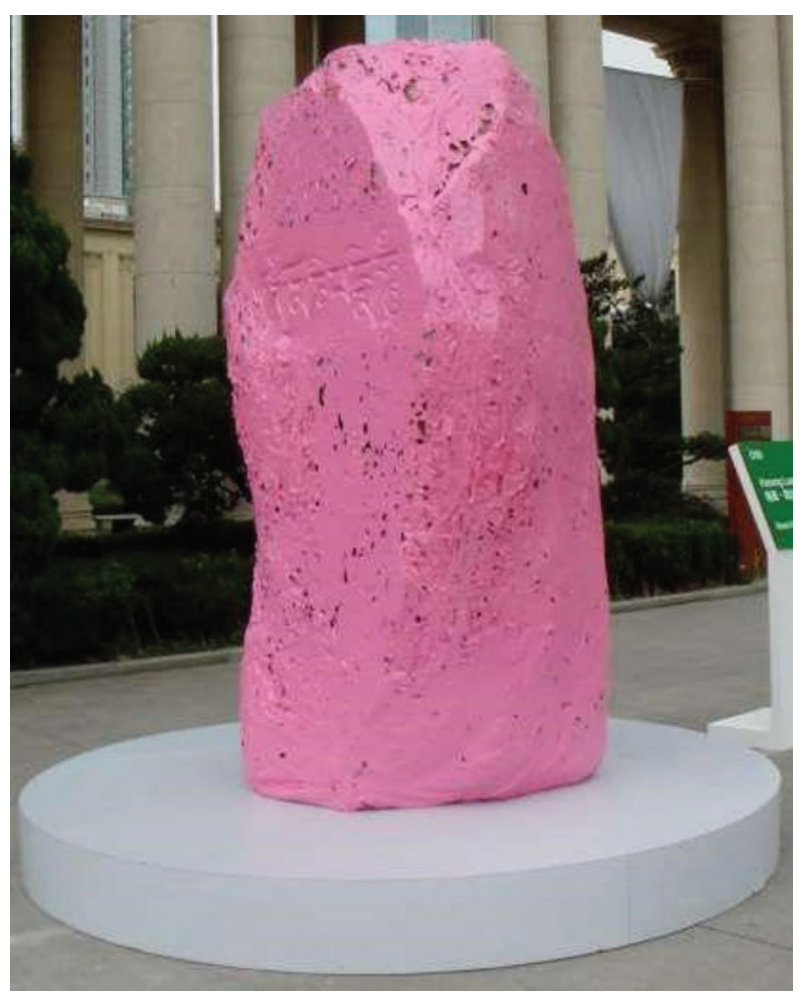

Figure 3: Pink Himalayan Boulder, Kesang Lamdark 2008 Courtesy of the artist

which it is exhibited to elicit meaning. However, there is a difference between Our Land, Our People, which is a reconstructed authentic space, Pink Himalayan Boulder, which refers to a location existing elsewhere, and Arak Stūpa, which reinterprets a spiritually charged built environment in the light of consumerism. A similar distinction was identified during the 1960s by an artist who helped developed the genre of Land Art.

Robert Smithson (1938-1973) became synonymous with Land Art in 1970, when he created Spiral Jetty at Rozel Point on the Great Salt Lake in Utah, USA. Smithson reshaped the shoreline into a curling peninsula extending into the lake. As part of the living landscape, this artwork is subject to fluctuating water depths and remained underwater until 1999, when it emerged newly festooned in white salt crystals (Tufnell 2006: 32, 41). Smithson's use of the landscape to create art corresponds with his dialectic of sites and non-sites. According to Smithson's logic, a site is intrinsic to physical reality, like Spiral Jetty. It cannot be moved without fundamentally undermining the integrity of the artwork. This means that while the curling land bridge is the focal point of Spiral Jetty, the shoreline, water, and sky are also elements of the artwork. Conversely, a non-site is a sample of a location that can be displayed in a gallery, like Lamdark's Pink Himalayan Boulder. By requiring viewers to see both sites and non-sites from an art-based perspective, Land Art attacked the idea of art as collectible objects. Yet, the question remains how to apply these ideas to Our Land, Our People. Is Rigdol's work a site or non-site? Is it comparable to Spiral Jetty or is it something else entirely? Tibetan Buddhist history may provide the answer to these questions.

By the $13^{\text {th }}$ century, a text known as the Cakrasamvara Tantra rose to prominence among Tibetan Buddhist scholars. As a product of the interrelationship between Buddhism and Hindu Śaiva traditions, this text marked a transition that incorporated a series of sites known as pițhas into an Indo-Tibetan Buddhist system. According to the scholar Alex McKay, the earliest texts to include the Puranic origin of the pițha network are the Kālikā Purāna $\left(11^{\text {th }} / 12^{\text {th }}-14^{\text {th }}\right.$ c.) and Devī Bhāgavata Purāna ( $13^{\text {th }} / 14^{\text {th }}$ c.). These texts describe how the Hindu God, Śiva, overcome with grief by the death of his wife, Sati, carried her corpse across the sky. Locations where parts of her decomposing body fell to earth became pițhas or 'seats' of Devī Śakti (McKay 2015: 96-97). Initially, there were only four pița sites, but their exact locations varied and were largely dictated by the preferences of the person who identified them. Later texts increased the total number of these locations to twenty-four, fifty, or one-hundred and eight. (McKay 2015: 96-97) Twenty-four pițha sites were identified across northern India as physical areas corresponding with points in the subtle body of the yoga practitioner. While Trika Śaivites, who originally developed these sites prior to the $11^{\text {th }}$ century, eventually disregarded geographic pitha, the creation of such locations gave rise to a phenomena Huber called "slippage" or instances in which cosmographical space became accessible via a topographical proxy (Huber 2008: 106). Of the twenty-four locations identified in the Cakrasamvara Tantra, the Devikoța pițha presents a tantalizing analogy to Tenzing Rigdol's site-specific installation.

Like the duplicated sites Lung Ngön monastery, there came to be four additional Devikoța pițhas, with the most recent iteration appearing in Tibet as late as the $19^{\text {th }}$ century. Each duplication was a product of complex political forces, such as the mid- $13^{\text {th }}$ century Islamic incursions into India which rendered holy sites inaccessible. Additionally, four historically significant figures played key roles in the proliferation of these sites. This includes the leader of the Drigung Kagyu Buddhist group, Jikten Gompo Rinchen Pel (1143-1217), the leader of the Gyalwang Drukpa Buddhist group, Kunkhyen Pema Karpo (1527-1592), as well as Sakya 
Paṇdita Kundga Gyaltsan (1182-1251) and Jamgon Kongtrul Lodro Thaye (1813-1899), two of the most prominent scholars in Tibetan history.

The saga of Devikota pithas began at a time when the Drigung Kagyu Buddhist group was particularly entrepreneurial. They set about transferring the sacred geography of India to Tibet by merging locations previously recognized as power-places. The Drigung Kagyu leader, Jikten Gompo Rinchen Pel sent people to assign new pița identities to three mountains, merging Mount Kailash with Himavat, Mount Labchi with Godavari, and Mount Tsari was doubly identified as both Cāritra and Devikoța. The Drigungpas justified this by claiming the local mountain deities and the Indian pițha protectors (San. kșetrapāla) were the same beings. The transference of Indian space to Tibet was so effective that Tsari continues to be regarded as Devikoța to this day (Huber 2008: 114). However, not everyone was pleased with the Drigunpa's plan. In his text, The Classifications of the Three [Types of Buddhist] Vows (Tib. Sdom gsum rab dbye), Sakya Paṇita Kundga Gyaltsan rebuked advocates of popular religious practices like circumambulating sacred sites and stated clearly that the pitha sites at Kailash and Tsari could not be substantiated. (Martin 1994: 286; Huber 1990: 127-130).

Sakya Pandita's criticism received numerous counterarguments by those with a vested interest in maintaining the pilgrimage sites. Among the Kagyu authors, this included the 4th Gyalwang Drukpa, Kunkhyen Pema Karpo (Martin 1994: 228; Huber 1990: 133). Pema Karpo's position in this matter was symptomatic of an ongoing schism between the scholastic and highly rational adoption of Indian Buddhism championed by Sakya Pandita and the so called "Buddha-isation" process in which Indian religious practices were superimposed over pre-existing Tibetan practices (Huber 1990: 130).

Pema Karpo identified two additional Devikoța pițhas, with the first in modern-day Bihar, while in his guidebook, The Pilgrimage Guide to Devikota in Lhodrag, Tibet (Tib. Bod yul lho de wi ko ta'i gnas bshad), he identified Mount Karchu in southern Lhodrag as the second. This was a "conscious act of revitalization of a holy place which served his [Pema Karpo's] particular interests at the time" (Huber 2008: 115). Since Pema Karpo was stationed far away from the wealth and patronage his lineage possessed, he needed to devise a means of securing these comforts. By "revitalizing" spaces, activating and absorbing them into the pițha network, he was able to benefit from the economic fruits of pilgrimage.

To justify his identification of two Devikoța pițhas, Pema Karpo deployed a variety of techniques. He posited the sites were geographical equivalents to the cosmographical right and left eyes, respectively (Huber 1990: 149). He also defended the sanctity of these sites by denouncing the karmic purity of those who could not perceive the location's cosmographical qualities. For instance, he provided the example that water is supposedly understood by gods as the elixir of immortality, as merely a thirst-quenching beverage by humans, and as pus and urine by hungry ghosts. Furthermore, he adopted the Drigungpa tactic of claiming both the kșetrapāla goddess and the male deity at the Tsari-Caritra pitha site were protector deities belonging to the retinue of the national protector deity of Tibet, Palden Lhamo (Huber 1990: 137, 147). Less than one hundred years later, a similar process was deployed to identify yet another a Devikoța pițha at Phabongka near Sera monastery.

While leaders of the Gelugpa Buddhist group, like Tsongkhapa Lobzang Drakpa (1357-1419) and the first Panchen Lama Lobzang Chokyi Gyaltsan (1567-1662) made the pilgrimage to Kailash and Tsari, establishing a Devikoța pița at Phabongka may have extended the political agency of this Buddhist lineage. Huber pointed out that the earliest claim of Devikoța existing at Phabongka appeared in the Fifth Dalai Lama's text A History of Tibet (Tib. Bod kyi deb ther), written in 1643 . While the proliferation of Devikoța sites led to competition and further questions regarding their legitimacy, a familiar resolution appeared in a $19^{\text {th }}$ century guidebook. The original pița in India was acknowledged alongside clarification that duplication did not negate the authenticity of Phabongka. This was due to the spiritual works performed by saints at the site (Huber 1990: 149-151; 2008: 116).

The fourth and final Devikoța is located at a somewhat obscure location known as Tsadra Rinchen Drak, a spot not formerly endowed with any sacred attributions. Huber explained there was "dire economic need and a bid for independence by a talented but powerless individual within a manipulative religiopolitical environment" (Huber 2008: 117). The individual to whom he referred is none other than Jamgon Kongtrul Lodro Thaye (1813-1899), a renowned author and ecumenical scholar known for compiling an extensive textual synthesis of the knowledge generated by many Tibetan Buddhist lineages. Jamgon Kongtrul Lodro Thaye was proclaimed an incarnate lama (Tib. sprul sku) by the Karma Kagyu hierarch of Palpung Monastery, the ninth Tai Situ Pema Nyinche Wangpo (1774-1853). However, his recognition as a reincarnation was meant to prevent Jamgon Kongtrul from being poached by the then rival Sakya Buddhist group who controlled the local government. As the first in a new 
incarnation lineage, Jamgon Kongtrul had no financial support with which to establish himself, so he went into retreat at the site that would become the fourth Devikota pițha.

To establish the site, the founding lamas utilized a specific type of treasure text (Tib. gter ma) called visionary revelation (Tib. bdag snang). As the name suggests, treasure texts are documents hidden or buried for later discovery or are believed to be transmitted from mind to mind. The founding lamas also wrote guidebooks and sacred place eulogies (Tib. gnas yig) to describe the impact of the site on those who practice there, particularly during pilgrimage gatherings (Huber 2008: 116). Endorsed by three potent religious leaders and reinforced by texts testifying to the site's authenticity, the newest Devikoța piț ha marked a culminating point when the sacred site became completely free. Removed from its Indian context, the site was meant to be "an elaborate duplication of the very first Tibetan Devikoța" at Tsari (Huber, 2008: 117). The name itself (tsa 'dra rin chen brag) translates to 'Tsari-like jewel rock.'

In a guidebook Jamgon Kongtrul wrote between 1842-1859, he gave a detailed description of how the landscape could be understood according to the trikāya perspective, a Mahayana Buddhist conception of the nature of reality. Accordingly, the physical space of the fourth Devikota pitha was said to possess microcosmic properties corresponding to the energy channel (Tib. rtsa) of the eye. In its secondary identification as Caritra, the space also corresponded to the central energy channel running along the spine (Tib. rtsa dbu ma). Additionally, the site was attributed the macrocosmic palace of Vajrasattva along with "the Vajra lineage of Herukas with their retinues, beginning with Sri-Cakrasamvara” (Huber 1990: 153). While this constellation of attributes would certainly make any location an enviable site of pilgrimage, Jamgon Kongtrul assuaged any concerns about its duplicated nature. He explained that Tsadra Rinchen Drak possessed a "derivative status by being a 'branch' (yan lag) or 'division' (bye brags)" of both the original Indian site and the three other sites established in Tibet, but that this did not diminish the potency of the site (Huber 1990: 151-155). The propagation of the Devikota pithas across the south-eastern region of Tibet is indicative of a pattern within Tibetan Buddhist culture and confirms that, in certain instances, the existence of duplicate sites is not an issue according to a Tibetan Buddhist logic of space.

\section{Conclusion}

Considering the saga of the Devikota pițha, Rigdol's installation takes on refined layers of meaning. While establishing a new Devikota required the location to be absorbed within a pre-existing network of spaces and corresponding cultural practices, it was not necessary to physically transport the material substance of the original site. If the principles associated with relocating pitha sites to Tibet were applied to Rigdol's installation, he could have arrived in Dharamsala, stated that a designated area was now a Tibetan territory, and reinforced this claim by writing texts. However, to reterritorialize Dharamsala as a new Tibet would undermine its symbolic potency as the home of a displaced people. Further, by violating multiple international borders, Our Land, Our People was directly concerned with geopolitics that currently disfavor the Tibetan right to self-determination. By appropriating the tradition of transporting space, Rigdol circumvented this reality, if only momentarily.

Moreover, when considered in relation to Robert Smithson's dialectic of sites and non-sites, the act of physically relocating Tibetan soil to Dharamsala defines the installation as a non-site. The soil was a sample of a location. It was removed and intended for display. Theoretically, the installation could have been installed anywhere, although a different location would likely diminish the artwork's effects. However, over the course of the exhibition, the stage surmounted by Tibetan dirt appeared to retain the properties of the homeland. Our Land, Our People initially functioned as a non-site signifier, a reference to a space existing elsewhere, but as visitors wept over a fragment of natal space it was transformed by the viewer's response into an intrinsic physical reality. This mirrors Huber's concept of "slippage" in which a topographical proxy provides access to another space (Huber 2008: 106). Tsering Wangmo Dhompa once wrote that "Nostalgia is political in our experience as 'Tibetans,' and [...] Tibet is approached with a reverence and an elegiac tone reserved for people and places irretrievably lost" (Dhompa 2005). By mobilizing aspects of a Tibetan Buddhist logic of space, Tenzing Rigdol demonstrated that Tibet is not "irretrievably lost."

The phrase Bringing Tibet Home, the title of the documentary that traces Rigdol's installation from conception to completion, suggests the homeland is portable but not necessarily home. The implication is that home can only be where the historical socio-political environment of 
Jay Daugherty (MPhil, Tibetan \& Himalayan Studies, University of Oxford, 2017) is an independent researcher of contemporary art. He earned a BA in Fine Art from Purdue University and an MA in Art History from the University of London, SOAS. In addition to writing about art and Tibetan cultural history, he is an exhibiting contemporary artist.

I wish to thank Sara Collins, Joie Chen, and Dr. Harmandeep Gill for providing editorial feedback at various stages of this research. Additionally, this project would not have been possible without the supervision of Dr. Ulrike Roesler and the generous support of His Holiness the 12th Gyalwang Drukpa.

Tibet and His Holiness the XIV Dalai Lama are united. The act of collectively viewing the soil and interacting with it publicly rendered the installation a non-site, a work of art created for exhibition that referred to a space existing elsewhere, but as individual observers interacted with the soil, collecting portions to keep or even consume, they demonstrated through their behavior that the soil was considered equivalent to the signified object of natal space. The installation became an actual site. Unlike artworks created under the Land Art moniker, Tenzing Rigdol's Our Land, Our People is not limited to either end of Smithson's dialectic. The installation is both a representation of Tibetan space and a temporary sovereign territory saturated with the energy of the homeland. By re-enacting a culturally specific historical practice of moving space, Rigdol created something entirely new. In the end, Our Land, Our People is best understood as a metonym. Standing on the stage surmounted by Tibetan earth performs the function of possessing land, the attainment of freedom.

\section{References}

Buffetrille, Katia 2015. "Some Remarks on Bya rung kha shor and others Buddhist Replicas in Amdo." In From Bhakti to Bon: Festschrift for Per Kvcrne, edited by H. Havnevick and C. Ramble, 133-152. Oslo: NOVUS.

Cole, Susan. G. 2004. Landscapes, Gender, and Ritual Space: The Ancient Greek Experience. Berkeley, California; London: University of California Press.

Crowther, Paul. 2013. Phenomenologies of Art and Vision: A Post-Analytic turn. London; New York: Bloomsbury.

Dhompa, Tsering Wangmo. 2005. "Nostalgia in Contemporary Tibetan Poetics." Mechak Center for Contemporary Tibetan Art, http://www.mechakgallery. com/nostalgia_in_contemporary_tibetan_poetics.html, (accessed on 4 September 2017).

Flood, Gavin. 1999. Beyond Phenomenology: Rethinking the Study of Religion. London: Cassell.

Foucault, Michel. 1991. "Space, Knowledge and Power" In The Foucault Reader: An Introduction to Foucault's Thought, edited by P. Rabinow. 239-256. London: Penguin.

Gilhuly, Kate and Nancy Worman, eds. 2014. Space, Place, and Landscape in Ancient Greek Literature and Culture. Cambridge: Cambridge University Press.

Harris, Clare. 2012. "In and Out of Place: Tibetan Artists' Travels in the Contemporary Art World." Visual Anthropology Review 28(2): 152-163.

Harvey, David. 1993. "From Space to Place and Back Again: Reflections on the Condition of Postmodernity." In Mapping the Futures: Local Cultures, Global Change, edited by J. Bird, T. Curtis, G. Putnam and L. Tickner, 3-19. London and New York: Routledge.

Horden, Peregrine and Nicholas Purcell. 2000. The Corrupting Sea: A Study of Mediterranean History. Oxford: Blackwell.

Huber, Toni. 1990. “Where Exactly Are Caritra, Devikota and Himavt? A Sacred Geography Controversy and the Development of Tantric Buddhist Pilgrimage Sites in Tibet." Kailash 16(3-4): 121-164.

2008. The Holy Land Reborn. Chicago: University of Chicago Press.

Lefebvre, Henri. 1991. The Production of Space. Translated by Donald Nicholson-Smith. Oxford: Wiley-Blackwell.

Martin, Dan. 1994. "Pearls from Bones: Relics, Chortens, Tertons and the Signs of Saintly Death in Tibet." Numen 41(3): 273-324.

Masters, H.G. 2010. “Enlightenment May Not Be Possible in This Lifetime: Strive for Your Own Liberation with Laughter and Diligence." In Tradition Transformed: Contemporary Artists from Tibet, edited by Elaine W. Ng. New York: Arts Asia Pacific \& Rubin Museum of Art.

McKay, Alex. 2015. Kailas Histories: Renunciate Traditions and the Construction of Himalayan Sacred Geography, edited by Henk Blezer, Alex McKay and Charles Ramble. Leiden \& Boston: Brill.

Merleau-Ponty, Maurice. 2002. Phenomenology of Perception. London: Taylor \& Francis. 
Osborne, Robin. 1987. Classical Landscape with Figures: The Ancient Greek City and Its Countryside. London: George Philip.

Pollock, Sheldon. 2006. The Language of the Gods in the World of Men: Sanskrit, Culture, and Power in Premodern India. Berkeley, Los Angeles, London: University of California.

Quintman, Andrew. 2008. "Toward a Geographic Biography: Mi la ras pa in the Tibetan Landscape." Numen 55(4): 364-410.

Rekjong, Dhondup Tashi. 2013. "Introduction" In Darkness into Beauty. Compiled by Martin Clist. London: Rossi and Rossi.
Robinson, Betsey. 2011. Histories of Peirene: A Corinthian Fountain in Three Millennia. Princeton: American School of Classical Studies at Athens.

Soja, E. W. 1989. Postmodern Geographies: The Reassertion of Space in Critical Social Theory. London: Verso.

\section{.1996. Thirdspace: Journeys to Los Angeles and Other} Real-and-Imagined Places. Cambridge, MA: Basil Blackwell. Tufnell, Ben. 2006. Land Art. London: Tate.

Van Dyck, Ruth M. and Susan E. Alcock, eds. 2003. Archaeologies of Memory. Oxford: Blackwell. 